AECD - 2683

UNITED STATESATOMIC ENERGY COMMISSION

\title{
THE ALLOY SYSTEMS URANIUM-ALUMTNUM AND URANIUM-IRON
}

by

Paul Gordon

A. R. Kaufmann

Massachusetts Institute of Technology

Date Declassified: August 26, 1949

Issuance of this document does not constitute authority for declassification of classified copies of the same or similar content and title and by the same author.

Technical Information Division, ORE, Oak Ridge, Tennessee AEC, Oak Ridge, Tenn., 2-20-50--650-A10228

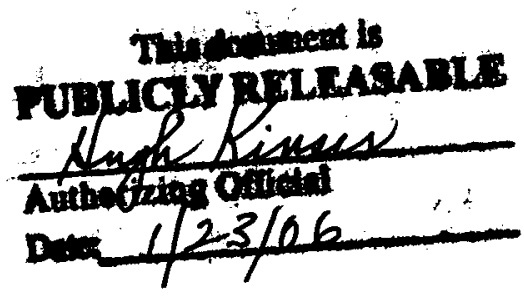




\section{DISCLAIMER}

This report was prepared as an account of work sponsored by an agency of the United States Government. Neither the United States Government nor any agency Thereof, nor any of their employees, makes any warranty, express or implied, or assumes any legal liability or responsibility for the accuracy, completeness, or usefulness of any information, apparatus, product, or process disclosed, or represents that its use would not infringe privately owned rights. Reference herein to any specific commercial product, process, or service by trade name, trademark, manufacturer, or otherwise does not necessarily constitute or imply its endorsement, recommendation, or favoring by the United States Government or any agency thereof. The views and opinions of authors expressed herein do not necessarily state or reflect those of the United States Government or any agency thereof. 


\section{DISCLAIMER}

Portions of this document may be illegible in electronic image products. Images are produced from the best available original document. 
THE ALLOY SYSTEMS URANIUM-ALUMTNUM AND URANIUM-IRON*

By Paul Gordon $\dagger$ and A. R. Kaufmann $\ddagger$

\section{INTRODUCTION}

The large-scale manufacture and use of uranium in conjunction with the atomic energy development during the war led to a need for knowing the equilibrium diagrams of uranium with various other metals. The alloys of uranium with aluminum and with iron were among the first that were studied for this purpose. Much of the work was done in the manner of a survey since the need was to determine the important features of the phase diagrams rather than to obtain completely detailed results. For this reason no attempt was made to locate exactly such features as liquidus lines, solid solubility limits, and compound and eutectic compositions. It is believed, however, that there are no great inaccuracies in the diagrams reported here and that no important points were overlooked.

Earlier work on alloys of uranium with aluminum and iron is almost nonexistent and in each case is considered to have been of little value by $M$. Hansen. 1 It is interesting to note, however, that the compound $\mathrm{UAI}_{3}$ was first reported in 1902 by $\mathrm{L}$. Guillet.

\section{EXPERIMENTAL PROCEDURE}

\section{Materials}

The uranium used for making most of the aluminum alloys was obtained from material prepared by Metal Hydrides, Incorporated, and melted in vacuum at Massachusetts Institute of Technology. Because of the lack of an adequate supply of metal, it was necessary to use material from several different batches and, hence, it is impossible to state an exact analysis. However, a few results indicated abeut 0.01 to 0.03 per cent iron and probably about 0.03 to 0.05 per cent carbon. Toward the end of the work a small amount of metal was obtained from Brown University and from Iowa State College and this was used in determining the transformations in pure metal and in some dilute alloys. All of the aluminum used in this investigation came from a supply of high purity metal (greater than 99.9 per cent aluminum) which was obtained through the courtesy of Dr. Mehl of the Carnegie Institute of Technology.

The uranium used for making the alloys with iron was produced by the bomb reduction process which has been described by J. Chipman. 2 This metal, after vacuum melting, contained about 99.9 per cent uranium by weight with carbon and iron as the chief impurities. Electrolytic iron containing about 0.012 per cent carbon, 0.020 per cent nickel, and 0.009 per cent copper was used in making the melts.

\footnotetext{
*This work was carried out at the M.I.T. Metallurgical Project during the year 1943 under the sponsorship of the Manhattan Project (Contract W7405-eng-175).

†Assistant Professor of Physical Metallurgy, Illinois Institute of Technology.

$\$$ Associate Professor of Metallurgy, Massachusetts Institute of Technology.
} 
patterns without any treatment. The uranium-rich powders usually gave a weak pattern of $\mathrm{UO}_{2}$, but this did not interfere with observation of the lines due to the metal. Several attempts were made to quench uranium-rich powders from about $1000^{\circ} \mathrm{C}$ by breaking the quartz capsule under water, but this always yielded nothing but $\mathrm{UO}_{2}$. Calibration of the $\mathrm{x}$-ray film was done by means of tungsten lines.

\section{Heat-Treatment of Specimens}

Most of the alloys were examined as solidified but in certain cases it was necessary to heattreat and quench. This was accomplished by sealing off specimens, which were about $1 / 8 \mathrm{in}$. in diameter, in an evacuated quartz tube which was broken under water for the quench. The quartz tube was fastened to a block of nickel which served both to give a uniform temperature in the furnace and to act as a hammer for breaking the quartz.

It was found that the uranium-rich alloys would react with the quartz at temperatures above $1000^{\circ} \mathrm{C}$ and pick up enough silicon to alter the microstructure. In order to avoid this, the specimens were placed inside tiny cups of $\mathrm{BeO}$ and then sealed up as before. This technique was satisfactory up to about $1300^{\circ} \mathrm{C}$, at which temperature the devitrification of the quartz became serious. A small amount of heat-treatment at temperatures up to $1400^{\circ} \mathrm{C}$ was carried out in an atmosphere of purified helium which was maintained under slight pressure inside a Zircofrax tube. This arrangement gave sufficient protection from oxidation to allow at least several hours heat-treatment. Some of the aluminum-rich alloys were heat-treated at 500 to $600^{\circ} \mathrm{C}$ for as long as a week in a vacuum of about $10^{-2} \mathrm{~mm} \mathrm{Hg}$ without serious oxidation.

\section{Thermal Measurements}

After removing a portion of the ingot for metallographic examination, the remainder of the specimen was used for thermal analysis. A hole was drilled into the softer specimens to receive the thermocouple while the harder and more brittle alloys were crushed to a powder which was packed around the thermocouple. A bare thermocouple was used for some of the lower temperature measurements in the solid state, while a magnesia tube was used for protection against the uraniumrich alloys at higher temperatures and a quartz tube inside a magnesia tube was used for the highaluminum alloys. This amount of protection was necessary because of the aluminum vapors which quickly attacked the platinum-platinum-rhodium thermocouple.

Observations were made in a resistance furnace using the inverse rate method and taking readings every $5^{\circ} \mathrm{C}$, althougin this was sometimes reduced to $1^{\circ} \mathrm{C}$. The heating or cooling rate generally was about 5 to $10^{\circ} \mathrm{C}$ per minute, but sometimes was as low as $1^{\circ} \mathrm{C}$ per minute. Several attempts were made to secure a constant rate of heating or cooling. One of these consisted of using a temperature controller and two thermocouples to maintain a constant temperature difference between the specimen and the furnace. This procedure was satisfactory in the lower ranges of temperature, but led to spurious effects above about $1200^{\circ} \mathrm{C}$. A variation of the technique was to maintain the temperature difference manually instead of with a controller and this was more satisfactory since it avoided the small fluctuations due to the on-and-off cycle of the controller. Another method consisted of driving the temperature setting of the controller slowly up or down, but this again did not give a sufficiently smooth variation. The procedure which was finally adopted was simply to. raise or lower the voltage applied to the furnace by increments large enough to effect a change of about 200 to $400^{\circ} \mathrm{C}$ in the temperature and then to conduct readings during the time that the rate of change of temperature was satisfactory. This meant a certain amount of repetition in order to get the temperature ranges to overlap but the method still was considered more satisfactory than the others.

The thermal measurements up to about $1550^{\circ} \mathrm{C}$ were made in the apparatus shown in Fig. 2. Most of the work was done in a vacuum of the order of $10^{-3} \mathrm{~mm} \mathrm{Hg}$, but occasionally an argon atmosphere was used. "The quartz tube, which formed the vacuum chamber, was prevented from collapsing at the high temperatures by the thin graphite tube inside of it. The quartz lasted a long time at temperatures up to $1300^{\circ} \mathrm{C}$, but was good for only about 10 to $20 \mathrm{hr}$ at $1400^{\circ} \mathrm{C}$ and 2 to $4 \mathrm{hr}$ at $1500^{\circ} \mathrm{C}$. A few rough observations were made at temperatures above $1550^{\circ} \mathrm{C}$ using induction heating in the regular melting furnace and reading temperature as a function of time. 
$X$-ray diffraction patterns of alloys with increasing aluminum content substantiate the conclusion that no additional phases exist between uranium and the compound $\mathrm{UAl}_{2}$. The identification of this compound as $\mathrm{UAl}_{2}$ is based on microscopic examination of the alloys and on the crystal structure determined by $x$ rays. Because of the difficulty with chemical analysis and inhomogeneity in the alloys the micro-examination could not fix the location to better than about \pm 2 atomic per cent. The $x$-ray crystal structure analysis was not carried out far enough to give a unique molecular formula for the compound, but comparison of the density obtained by direct measurement with that calculated from the measured unit cell gave fairly good substantiation to the formula $\mathrm{UAl}_{2}$; values of $\sin ^{2} \theta$ using copper $\mathrm{K}$-alpha radiation are given in Table 1 . The lines may be indexed on a diamond cubic pattern with $a_{o}=7.74 \mathrm{~A}$. This must mean that there are 8 uranium atoms to a unit cell, since the scattering from the aluminum atoms is very small, and hence there would be 16 aluminum atoms in a unit cell if the formula $\mathrm{UAl}_{2}$ is correct. With this number of atoms to a cell, the $\mathrm{x}$-ray density is $8.38 \mathrm{~g} / \mathrm{cm}^{3}$, while the measured density is $8.21 \mathrm{~g} / \mathrm{cm}^{3}$. This is a fairly good check considering the experimental difficulty of getting a sound and homogeneous alloy, but the result probably is not good enough to prove the formula $\mathrm{UAl}_{2}$. A calculation of line intensities, which would prove this point, was not made at Massachusetts Institute of Technology.

The melting point of $\mathrm{UAl}_{2}$ was not uniquely determined because of the difficulties encountered at high temperature. The thermal effect shown at about $1590^{\circ} \mathrm{C}$ is believed to be significant, but it was obtained under poor conditions using induction heating. No evidence of an appreciable solid solution range on either side of this compound was found.

The next phase on the aluminum side of $\mathrm{UAl}_{2}$ is the compound $\mathrm{UAl}_{3}$, and in this case the formula has been proved to be correct by an x-ray crystal structure determination. The $\sin ^{2} \theta$ values together with the line intensities and indices for the diffraction pattern of $\mathrm{UAl}_{3}$ are given in Table 2. The pattern is that of a simple cube with relatively small deviation from the expected line intensities. This must mean that the uranium atoms are at the corners of a cube and, if aluminum atoms are placed at the faces of the cube, the calculated line intensities check very closely with the observed values. The lattice parameter of the cube is $4.27 \mathrm{~A}$ and, taking one uranium atom and three aluminum atoms to a unit cell, a calculated density of $6.8 \mathrm{~g} / \mathrm{cm}^{3}$ is obtained. The measured density is only $6.4 \mathrm{~g} / \mathrm{cm}^{3}$, but the disagreement with the calculated value is due to the difficulty in getting a homogeneous specimen of fairly large size.

Alloys between $\mathrm{UAl}_{2}$ and $\mathrm{UAl}_{3}$ show a two-phase structure with each constituent in massive form as shown in the photomicrograph, Fig. 7a. This structure, along with the clear-cut thermal data shown in Fig. 3, proves that $\mathrm{UAl}_{3}$ forms by means of a peritectic reaction between $\mathrm{UAl}_{2}$ and liquid. The peritectic temperature, as observed on alloys during heating, is located at about $1350^{\circ} \mathrm{C}$. No attempt was made to determine the exact extent of the peritectic line into the liquid field.

A third compound, which is considered to be UAl 5 , occurs on the aluminum side of $\mathrm{UAl}_{3}$. The chief evidence for the existence of this compound is given by $x$-ray diffraction patterns and by the consistent thermal data, which indicate a peritectic reaction between $\mathrm{UAl}_{3}$ and liquid at about $730^{\circ} \mathrm{C}$ (Fig. 3). The formula $\mathrm{UAl}_{5}$ has not been definitely proved since the crystal structure has not been obtained from the $x$-ray diffraction pattern; the $\sin ^{2} \theta$ values and line intensities, however, are listed in Table 3. Metallographic examination places the compound in the vicinity of $\mathrm{UAl}_{5}$, Jut again difficulties with inhomogeneity and chemical analysis precluded a more precise determination.

Cast alloys between $\mathrm{UAl}_{3}$ and $\mathrm{UAl}_{5}$ exhibited a rather indecisive two-phase structure which contained the two compounds in massive form in a matrix composed largely of the same two phases in a finely divided state. This microstructure persisted even after a fairly long heat treatment just below the peritectic temperature as shown in Fig. $7 \mathrm{~b}$. Some of this matrix probably also was aluminum due to the peritectic reaction not having gone to completion, but there was not enough of it to appear in the diffraction patterns. Thermal measurements usually gave a weak indication of the eutectic at $640^{\circ} \mathrm{C}$ (between $\mathrm{UAl}_{5}$ and $\mathrm{Al}$ ) in the alloys lying ketween $\mathrm{UAl}_{3}$ and $\mathrm{UAI}_{5}$ and this was apparently due to residual aluminum. An 80 per cent aluminum specimen which was annealed at $700^{\circ} \mathrm{C}$ for about a week gave only a very feeble effect at $640^{\circ} \mathrm{C}$, whereas in the cast condition this thermal break had been much stronger. 


\section{$\because \cdots$}

begin to melt until a temperature of $975^{\circ} \mathrm{C}$ is reached, and it is not completely molten until $1115^{\circ} \mathrm{C}$ is attained.

2. The solubility of iron in alpha and beta uranium, and of uranium in alpha iron is practically negligible.

3. The gamma iron field is quite limited. Its actual extent has not been determined, but is known to be less than 0.5 atomic per cent of uranium.

4. At the uranium-rich end, there is a peritectic reaction which occurs at $815^{\circ} \mathrm{C}$ involving the phases gamma uranium, liquid, and $\mathrm{U}_{6} \mathrm{Fe}$.

5. At $770^{\circ} \mathrm{C}$, a eutectoid reaction takes place between the phases gamma uranium, beta uranium, and $\mathrm{U}_{6} \mathrm{Fe}$. The eutectoid composition has been placed somewhat below 1 atomic per cent iron in view of the fact that specimens of the 1.0 atomic per cent iron alloy quenched from above the eutectoid temperature still show the presence of some $U_{6} \mathrm{Fe}$ in the form of globules quite a bit larger than the eutectoid particles in Figs. 10a and $10 \mathrm{~b}$.

6. A phase change between alpha and beta uranium appears at $675^{\circ} \mathrm{C}$ in the composition range between almost pure uranium and the compound $\mathrm{U}_{6} \mathrm{Fe}$.

7. Between the two compounds $\mathrm{U}_{6} \mathrm{Fe}$ and $\mathrm{UFe}_{2}$ a eutectic transformation occurs at the surprisingly low temperature of $725^{\circ} \mathrm{C}$.

8. The compound $\mathrm{UFe}_{2}$ melts at $1235^{\circ} \mathrm{C}$ creating an open maximum in the diagram.

9. At $1080^{\circ} \mathrm{C}$ another eutectic transformation appears, involving $\mathrm{UFe}_{2}$, gamma iron, and liquid.

10. The alpha to gamma transformation in iron occurs at about $910^{\circ} \mathrm{C}$. In this case, the thermal data were somewhat inconsistent. The thermal holds obtained on the alloys containing 91.8 atomic per cent iron and above were all somewhat high. The $\mathbf{8 0 . 5}$ atomic per cent iron alloy showed the alpha to gamma break only after complete homogenizing, and even then a large spread between the thermal holds of cooling and heating appeared as indicated in Fig. 9. The microscopic evidence of this transformation was quite definite, however. Specimens of the 80.5, 91.8, and 99.0 atomic per cent iron alloys were quenched from just below and just above $910^{\circ} \mathrm{C}$. The resulting microstructures for the 91.8 atomic per cent iron alloy are illustrated in Fig. 16. The Widmanstätten structure appearing in the iron phase of the specimens quenched from just above $910^{\circ} \mathrm{C}$ is good proof that the iron has undergone a phase change. There is some sign of very finely dispersed precipitated particles in the iron phase, which is probably a result of the alpha to gamma transformation (see Fig. $14 \mathrm{~d}, 15 \mathrm{~b}$, and $15 \mathrm{~d})$.

11. The details of the diagram in the vicinity of the delta iron transformation and the melting point of iron are somewhat doubtful. It is believed that the calibration of the thermocouple used was inconsistently low in this high temperature range. The melting point of iron, the temperature of the gamma-delta transformation, and the melting point of nickel in a check run were all from 15 to $25^{\circ} \mathrm{C}$ lower than the standard values given for these points. The thermal points plotted in Fig. 9 for the high iron alloys at and above the gamma transformation have, therefore, been plotted higher than the experimentally determined values by an amount $\left(25^{\circ} \mathrm{C}\right)$ sufficient to bring the melting point of iron up to the accepted value of $1535^{\circ} \mathrm{C}$. In all the alloys exhibiting the gamma-delta transformation, the temperature of this reaction remains the same as in pure iron, thus signifying negligible solid solubility of uranium in delta iron.

\section{PROPERTIES OF URANIUM-ALUMINUM AND URANIUM-IRON ALLOYS}

No systematic attempt was made to determine the physical properties of the uranium-aluminum alloys, but a few observations made in the course of the phase diagram study are worthy of mention. With regard to the three intermetallic compounds it may be said that all of them are brittle enough to be readily crushed with a hammer, but that none of them is hard enough to scratch glass. The densities of $\mathrm{UAl}_{2}$ and $\mathrm{UAl}_{3}$ are about 8.3 and $6.8 \mathrm{~g} / \mathrm{cm}^{3}$, respectively, while that of $\mathrm{UAl}_{5}$ was not determined. 
Table $1-\mathrm{X}$-ray Diffraction Results for $\mathrm{UAl}_{2}-$ Diamond Cubic Lattice: $\mathrm{a}_{0}=7.74 \mathrm{~A}$

\begin{tabular}{|c|c|c|}
\hline $\operatorname{Sin}^{2} \theta^{*}$ & hkl & Line Intensity $\dagger$ \\
\hline 0.0314 & 111 & $\mathrm{~W}$ to $\mathrm{M}$ \\
\hline 0.0816 & 220 & $\mathbf{s}$ \\
\hline 0.1126 & 311 & $\mathbf{S}$ \\
\hline 0.1615 & 400 & $\mathbf{w}$ \\
\hline 0.1922 & 331 & $\mathbf{M}$ \\
\hline 0.2425 & 422 & $\mathbf{s}$ \\
\hline 0.2714 & 511,333 & $\mathbf{S}$ \\
\hline 0.3208 & 440 & $\mathbf{M}$ \\
\hline 0.3505 & 531 & $\mathbf{M}$ \\
\hline 0.3994 & 620 & $\mathbf{M}$ \\
\hline 0.4305 & 533 & $\mathrm{M}$ to $\mathrm{W}$ \\
\hline 0.4790 & 444 & $\mathbf{w}$ \\
\hline 0.5088 & 711,551 & $\mathrm{~W}$ to $\mathrm{M}$ \\
\hline 0.5574 & 642 & $\mathbf{s}$ \\
\hline 0.5868 & 731,553 & S \\
\hline 0.6362 & 800 & Vw \\
\hline 0.6660 & 733 & Vw \\
\hline $0.7113 \ddagger$ & 822 & $M$ to $S$ \\
\hline $0.7408 \ddagger$ & 555 & $M$ to $S$ \\
\hline $0.7882 \ddagger$ & 840 & $\mathbf{M}$ \\
\hline $0.8174 \ddagger$ & 911 & $\mathbf{M}$ \\
\hline $0.8645 \ddagger$ & 664 & $\mathbf{M}$ \\
\hline $0.8940 \ddagger$ & 931 & $\mathbf{M}$ \\
\hline
\end{tabular}

*Values obtained with $\mathrm{Cu}-\mathrm{K}$ alpha radiation. t Vw - Very Weak; W-Weak; M-Medium; S-Strong. $\ddagger$ Last six values obtained with $\mathrm{Cu}-\mathrm{K}$ alpha $_{1}$ radiation. 
Table 3-X-ray Diffraction Results for $\mathrm{UAl}_{5}$ - Structure Not Determined

\begin{tabular}{|c|c|c|c|}
\hline $\operatorname{Sin}^{2} \theta^{*}$ & Line Intensity $\dagger$ & $\operatorname{Sin}^{2} \theta^{*}$ & Line Intensity $†$ \\
\hline 0.0166 & $\mathbf{W}$ & 0.3689 & $W$ to $M$ \\
\hline 0.0345 & $\mathbf{w}$ & 0.3893 & $\mathbf{w}$ \\
\hline 0.0454 & $\mathbf{W}$ & 0.4012 & vw \\
\hline 0.0529 & $\mathrm{VW}$ to $\mathrm{W}$ & 0.4081 & vw \\
\hline 0.0602 & $M$ to $S$ & 0.4184 & $\mathbf{W}$ to $\mathbf{M}$ \\
\hline 0.0965 & $\mathbf{M}$ & 0.4269 & $\mathbf{W}$ to $\mathbf{M}$ \\
\hline 0.1126 & $\mathbf{M}$ & 0.4408 & $\mathbf{V w}$ \\
\hline 0.1243 & $\mathrm{VW}$ to $\mathrm{W}$ & 0.4948 & $\mathbf{v w}$ \\
\hline 0.1255 & VW to $\mathrm{W}$ & 0.5035 & vw \\
\hline 0.1427 & $\mathrm{VW}$ to $\mathrm{W}$ & 0.5245 & $\mathbf{M}$ \\
\hline 0.1477 & Vw & 0.5349 & $\mathbf{M}$ to $\mathbf{S}$ \\
\hline 0.1615 & $\mathbf{w}$ & 0.5679 & VW \\
\hline 0.1693 & $\mathbf{w}$ & 0.5834 & $\mathbf{W}$ \\
\hline 0.1720 & $\mathbf{W}$ & 0.5954 & W to $M$ \\
\hline 0.1746 & $\mathbf{w}$ & 0.6039 & $\mathbf{w}$ \\
\hline 0.1827 & $\mathbf{w}$ & 0.6260 & $\mathbf{w}$ \\
\hline 0.1853 & $\mathbf{v w}$ & 0.6429 & $\mathbf{w}$ \\
\hline 0.2033 & vw & 0.6595 & $\mathbf{M}$ \\
\hline 0.2189 & vw & 0.6693 & $\mathbf{w}$ \\
\hline 0.2380 & s & 0.6824 & $\mathbf{w}$ \\
\hline 0.2500 & Vw & 0.7254 & $\mathbf{w}$ \\
\hline 0.2652 & $\mathbf{M}$ & 0.7486 & $\mathbf{w}$ \\
\hline 0.2824 & $\mathbf{W}$ to $M$ & 0.7737 & $\mathbf{w}$ \\
\hline 0.2903 & $\mathbf{W}$ to $\mathbf{M}$ & 0.7854 & $\mathbf{W}$ to $\mathbf{M}$ \\
\hline 0.2951 & W to $M$ & 0.8078 & $\mathbf{W}$ to $\mathbf{M}$ \\
\hline 0.3078 & $\mathbf{W}$ to $\mathbf{M}$ & 0.8306 & $\mathbf{W}$ \\
\hline 0.3192 & VW & 0.8460 & $\mathbf{w}$ \\
\hline 0.3290 & vw & 0.8692 & $\mathbf{M}$ \\
\hline 0.3439 & $\mathbf{W}$ to $\mathbf{M}$ & 0.8864 & $\mathbf{w}$ \\
\hline 0.3488 & $\mathbf{W}$ to $\mathbf{M}$ & 0.8983 & $\mathbf{w}$ \\
\hline 0.3605 & $M$ to $S$ & & \\
\hline
\end{tabular}

*Values obtained with $\mathrm{Cu}-\mathrm{K}$ alpha radiation.

tVW-Very Weak; W-Weak; M-Medium; S-Strong. 
Table 5-X-ray Diffraction Results for $\mathrm{U}_{6} \mathrm{Fe}$ - Lattice Structure Undetermined

\begin{tabular}{ll}
\hline \hline $\operatorname{Sin}^{2} \theta^{*}$ & Line Intensity ${ }^{\dagger}$ \\
\hline 0.0807 & W to $M$ \\
0.0975 & VW \\
0.1065 & VW \\
0.1175 & VW \\
0.1278 & M \\
0.1949 & W \\
0.2139 & W \\
0.2707 & VW \\
0.2934 & W to $M$ \\
0.3102 & VW \\
0.3605 & W to $M$ \\
0.3765 & W \\
0.3875 & W \\
0.4277 & W \\
0.4948 & VW \\
0.5061 & VW \\
0.5383 & VW \\
0.5799 & M \\
0.6961 & W \\
0.7215 & W \\
0.7401 & W \\
0.7522 & W \\
0.8125 & W to $M$ \\
0.8294 & W to $M$ \\
0.8460 & W to $M$ \\
0.8692 & W to $M$ \\
0.8830 & W to $M$ \\
\hline &
\end{tabular}

${ }^{*}$ Values obtained with $\mathrm{Cu}-\mathrm{K}$ alpha radiation.

Tvw - Very Weak; W-Weak; M-Medium; S-Strong. 


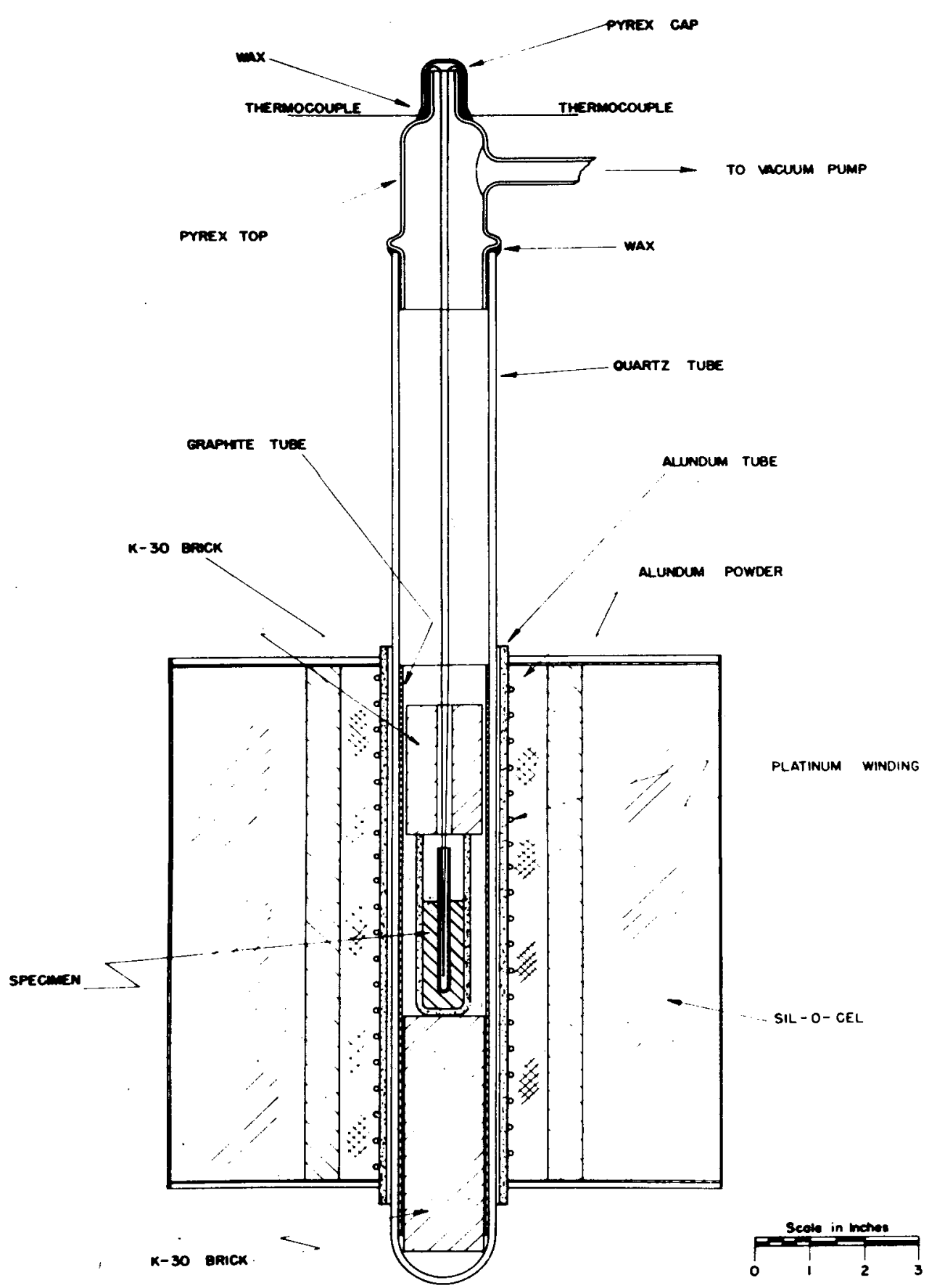

Fig. 2-Apparatus for thermal measurements. 


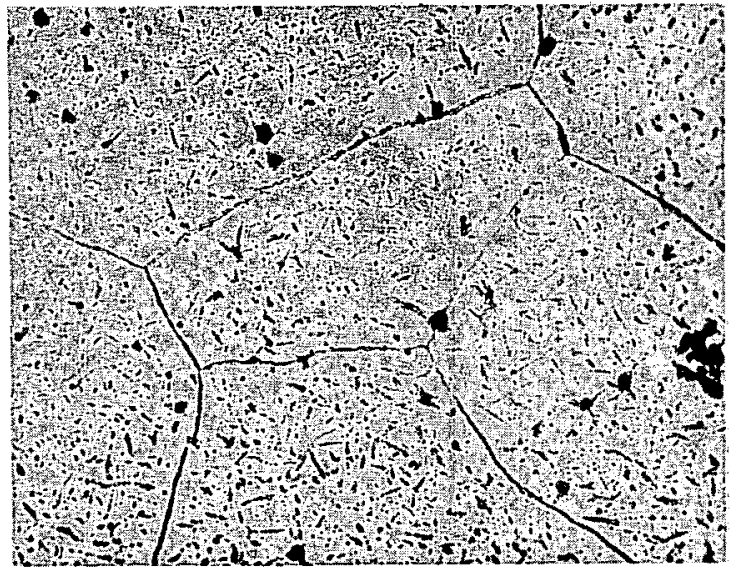

(a) $100 \mathrm{x}$

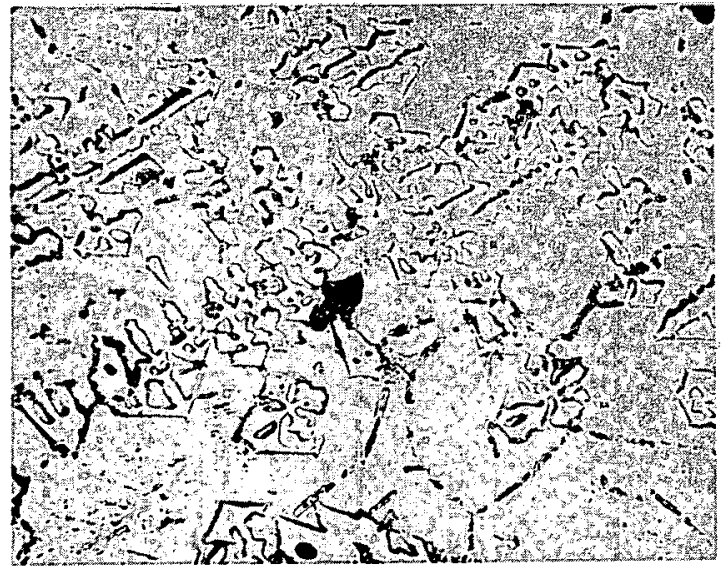

(b) $100 \mathrm{x}$

Fig. 4-Microstructures of cast uranium-aluminum alloys (electrolytic etch). (a) 5 atomic per cent $\mathrm{Al} ; \mathrm{UAl}_{2}$ at grain boundaries and within grains of uranium-rich eutectic. (b) 20 atomic per cent $\mathrm{Al}$; dendritic and grain boundary $\mathrm{UAl}_{2}$ in uranium-rich eutectic.

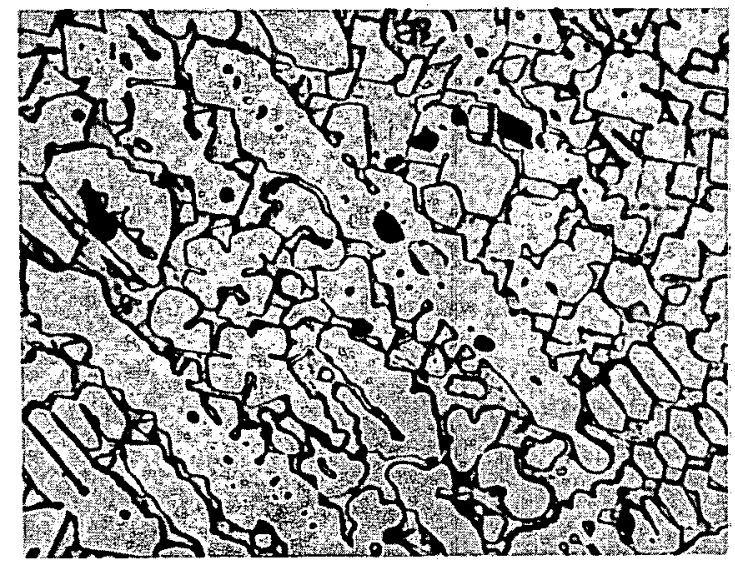

(c) $100 \mathrm{X}$

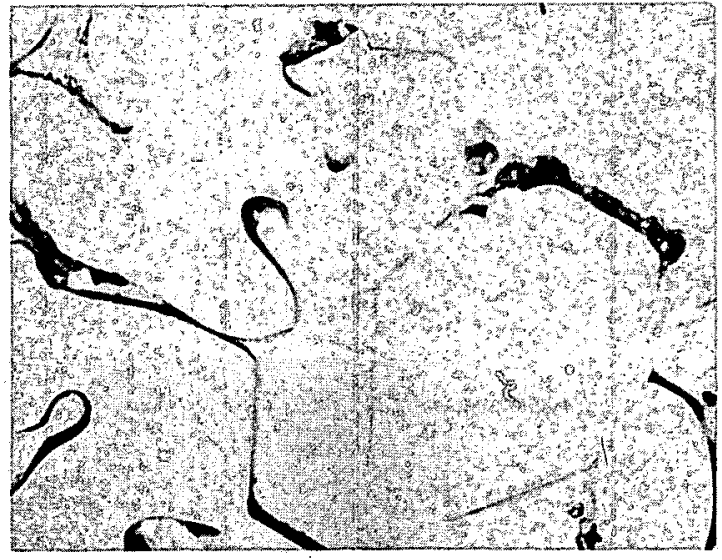

(d) $500 \mathrm{X}$

Fig. 4-Microstructures of cast uranium-aluminum alloys (electrolytic etch). (c), (d) 49 atomic per cent $\mathrm{Al}_{\text {; }}$ massive $\mathrm{UAl}_{2}$ in uranium-rich eutectic. 


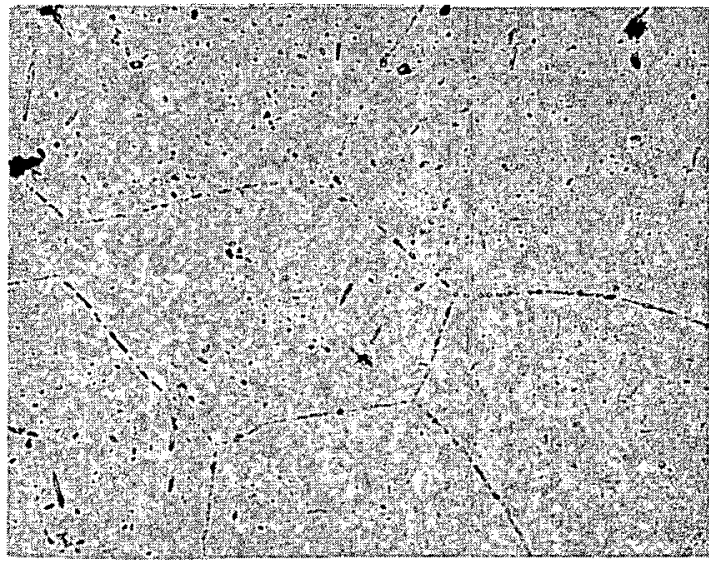

(a) $100 \mathrm{X}$

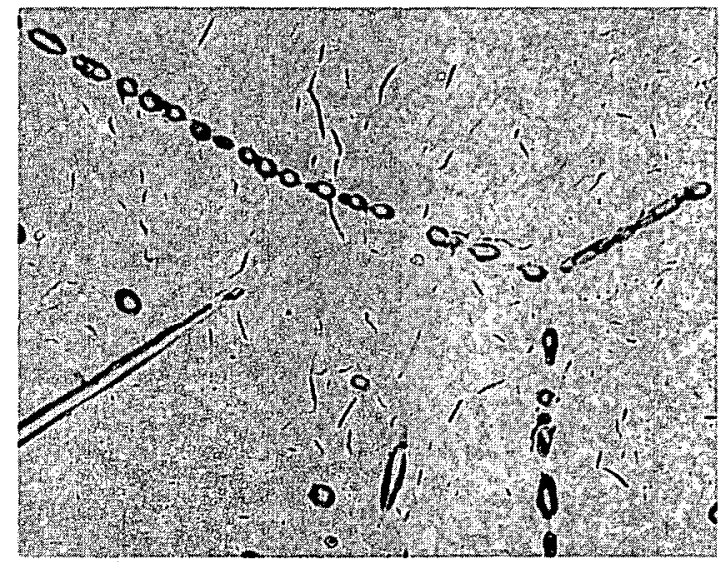

(b) $500 \mathrm{x}$

Fig. 6-Microstructures of quenched 5 atomic per cent aluminum alloy (electrolytic etch). (a), (b) Quenched from $1000^{\circ} \mathrm{C} ; \mathrm{UAl}_{2}$ in uranium-rich matrix.

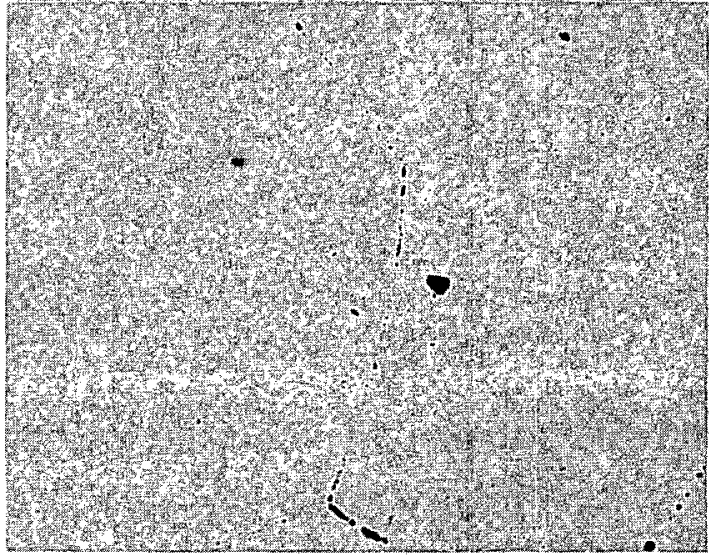

(c) $100 \mathrm{x}$

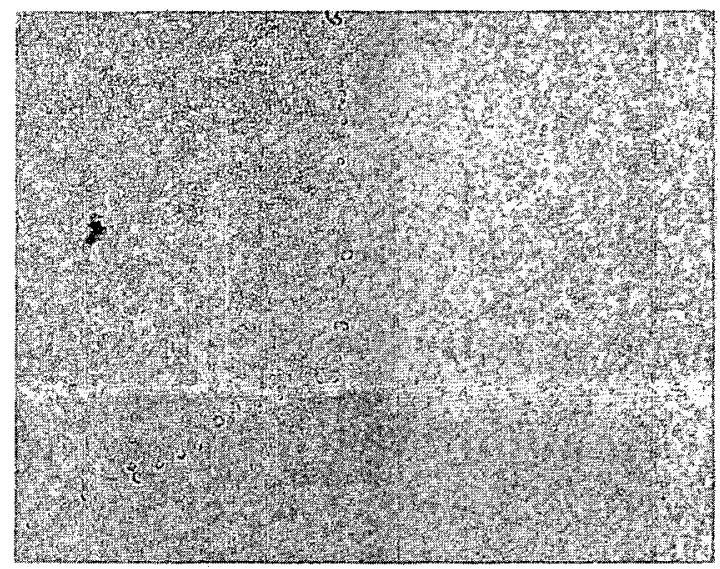

(d) $500 \mathrm{x}$

Fig. 6-Microstructures of quenched 5 atomic per cent aluminum alloy (electrolytic etch). (c), (d) Quenched from $1090^{\circ} \mathrm{C} ; \mathrm{UAl}_{2}$ in uranium-rich matrix. 


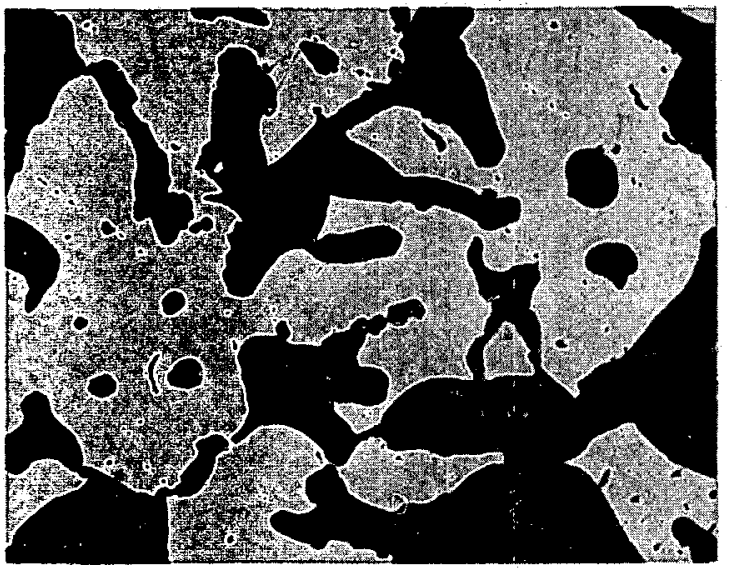

(a) $100 \mathrm{x}$

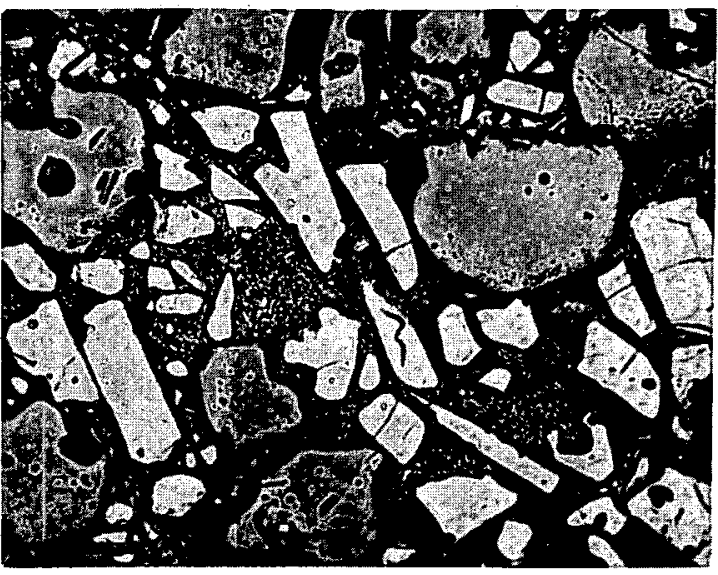

(b) $100 x$

Fig. 7 - Microstructures of cast uranium-aluminum alloys (1\% HF acid etch). (a) 70 atomic per cent Al; massive $\mathrm{UAl}_{2}$ and $\mathrm{UAl}_{3}$. (b) 80 atomic per cent $\mathrm{Al}$, heated to $710^{\circ} \mathrm{C}$ for $40 \mathrm{hr}$; massive $\mathrm{UAl}_{3}$ (dark) and massive $\mathrm{UAl}_{5}$ (light). Matrix is one or both of the two compounds finely divided.

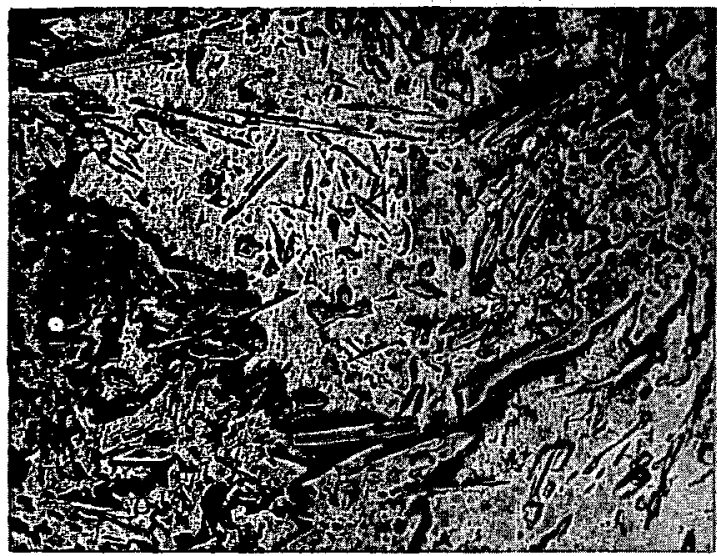

(c) $100 \mathrm{x}$

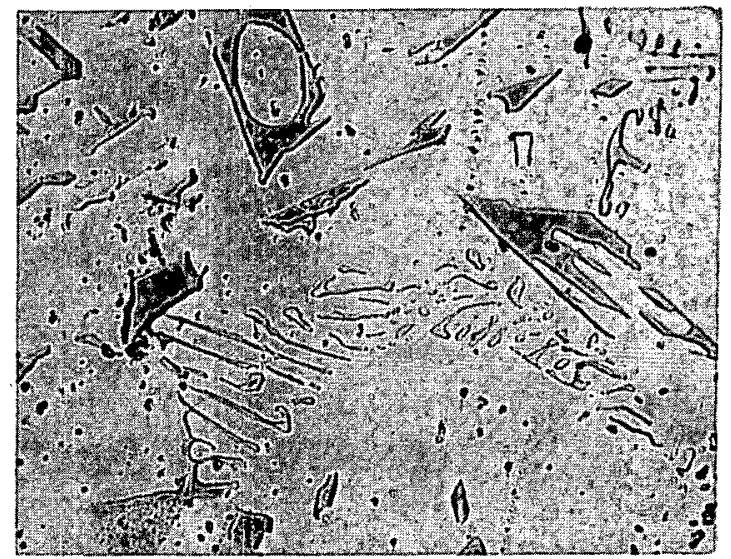

(d) $500 \mathrm{x}$

Fig. 7-Microstructures of cast uranium-aluminum alloys (1\% HF acid etch). (c), (d) 92.5 atomic per cent $\mathrm{Al}$; massive $\mathrm{UAI}_{5}$ and coarse eutectic of $\mathrm{UAl}_{5}$ and $\mathrm{Al}$. 


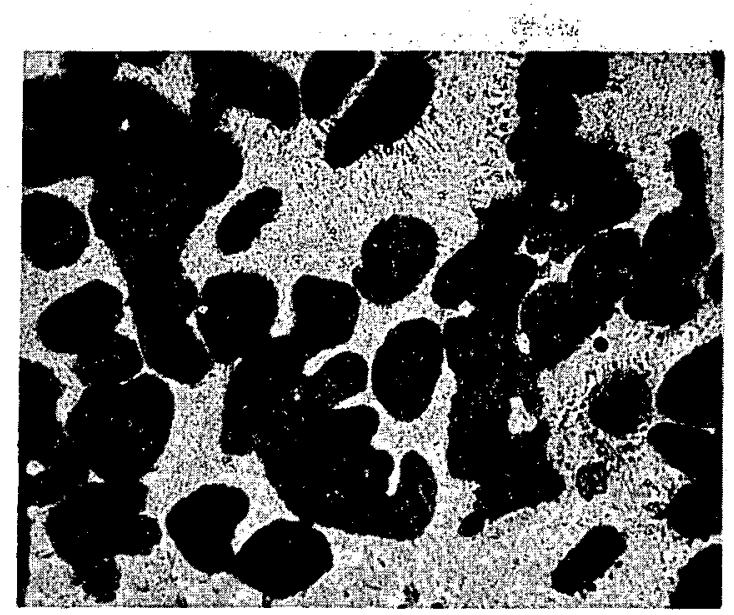

(a) $100 \mathrm{X}$

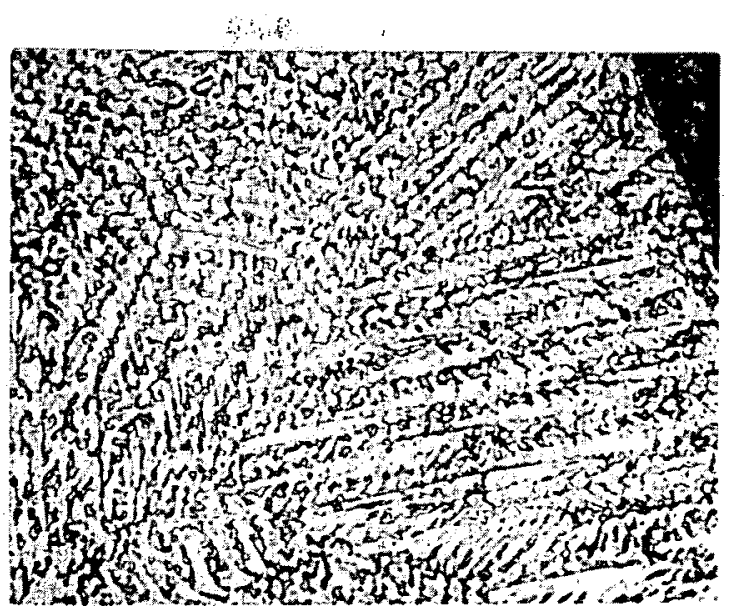

(b) $1000 \mathrm{x}$

Fig. 8-Microstructures of quenched 92.5 atomic per cent aluminum alloy (1\% $\mathrm{HF}$ acid etch). (a), (b) Quenched from $750^{\circ} \mathrm{C}$; massive $\mathrm{UAl}_{3}$ in dendritic matrix of $\mathrm{UAl}_{3}$ and $\mathrm{Al}$.

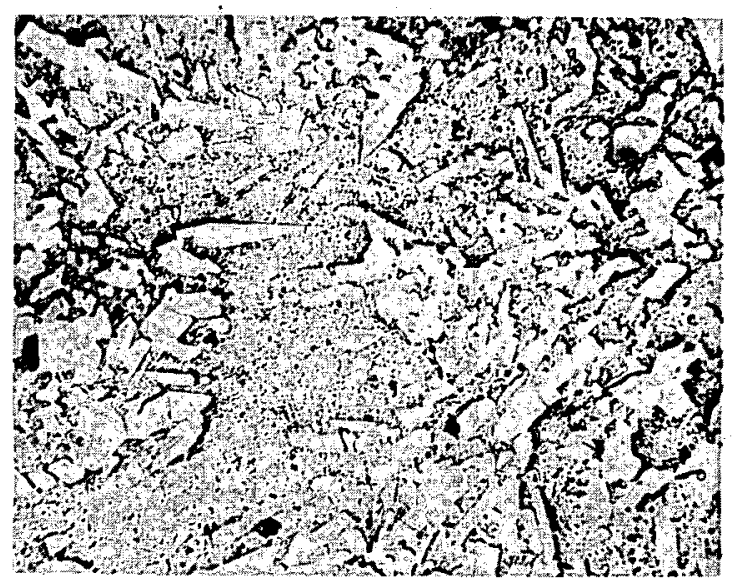

(c) $100 \mathrm{x}$

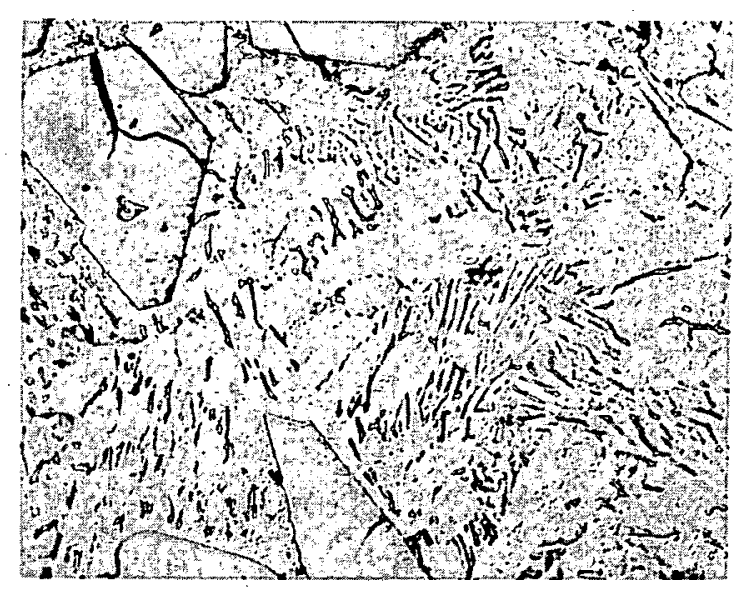

(d) $500 \mathrm{x}$

Fig. 8-Microstructures of quenched 92.5 atomic per cent aluminum alloy (1\% HF acid etch). (c), (d) Quenched from $675^{\circ} \mathrm{C}$; massive $\mathrm{UAl}_{5}$ in eutectic matrix of $\mathrm{UAl}_{5}$ and $\mathrm{Al}$. 


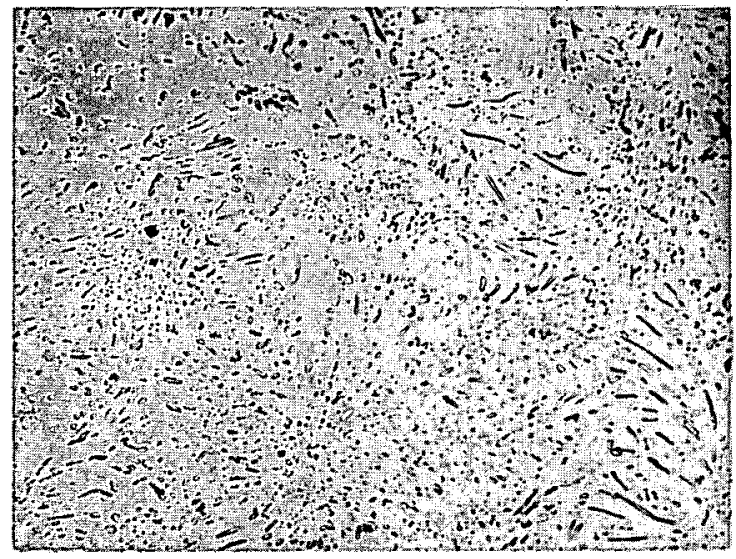

(a) $500 \mathrm{X}$

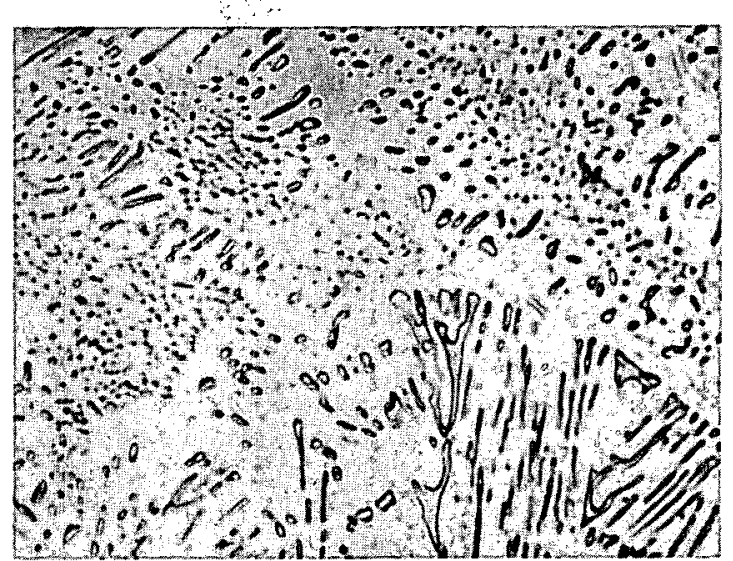

(b) $1000 \mathrm{X}$

Fig. 10-Microstructures of uranium-iron alloys in the as-cast condition (electrolytic etch). (a), (b) 1.0 atomic per cent iron; largely eutectoid of $U_{6} \mathrm{Fe}$ and $U$. Matrix is uranium phase.

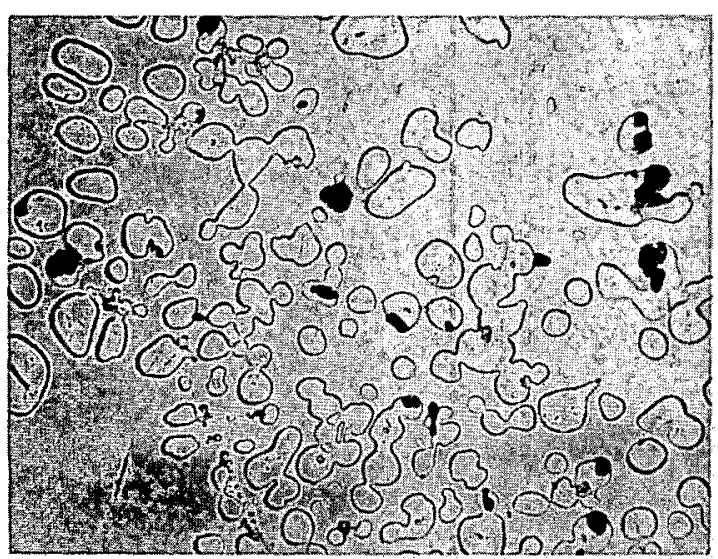

(c) $100 \mathrm{x}$

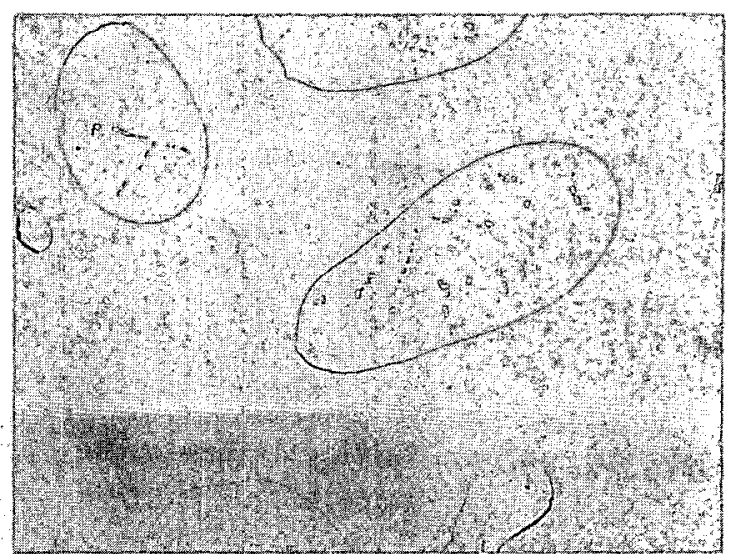

(d) $500 \mathrm{x}$

Fig. 10-Microstructures of uranium-iron alloys in the as-cast condition (electrolytic etch). (c), (d) 9.65 atomic per cent iron; peritectic structure; large globules of $U$ in $U_{6} F e$ matrix; precipitated $\mathrm{U}_{6} \mathrm{Fe}$ particles in $\mathrm{U}$ globules. 


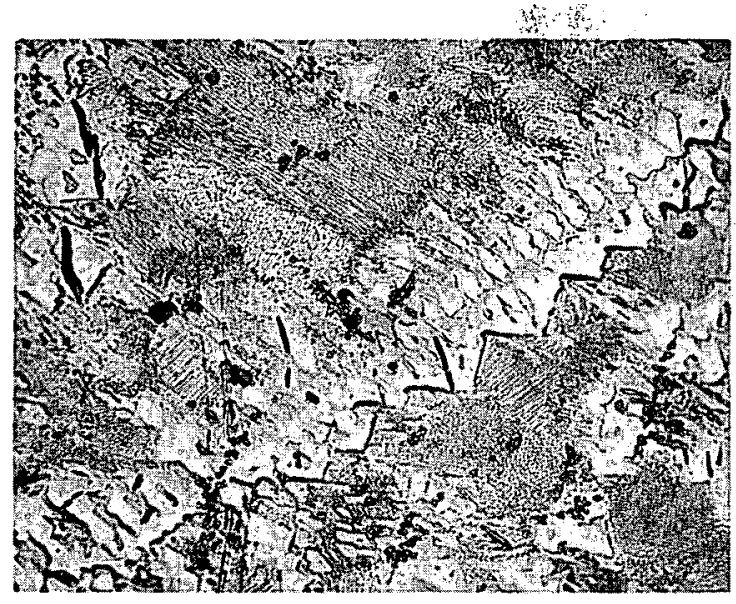

(a) $100 \mathrm{X}$

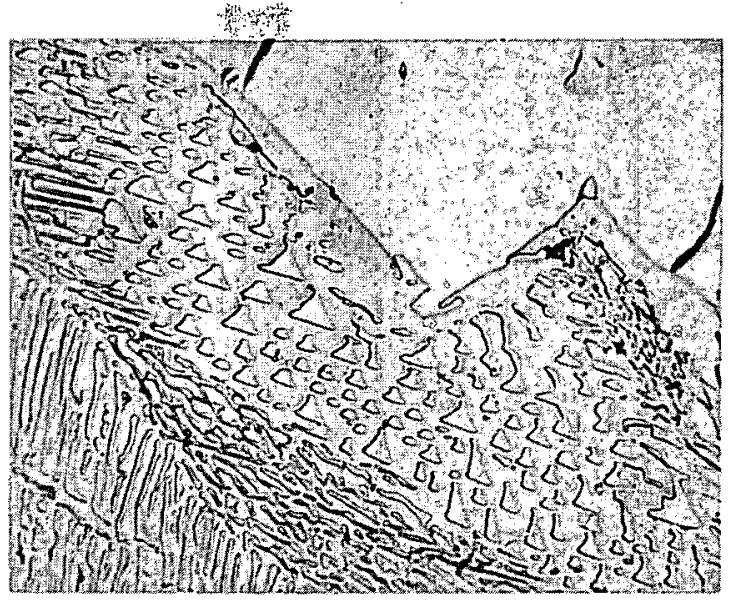

(b) $500 \mathrm{x}$

Fig. 12-Microstructures of uranium-iron alloys in the as-cast condition (electrolytic etch). (a), (b) 39.8 atomic per cent iron; massive $\mathrm{UFe}_{2}$ plus eutectic of $\mathrm{UFe}_{2}$ in $\mathrm{U}_{6} \mathrm{Fe}$.

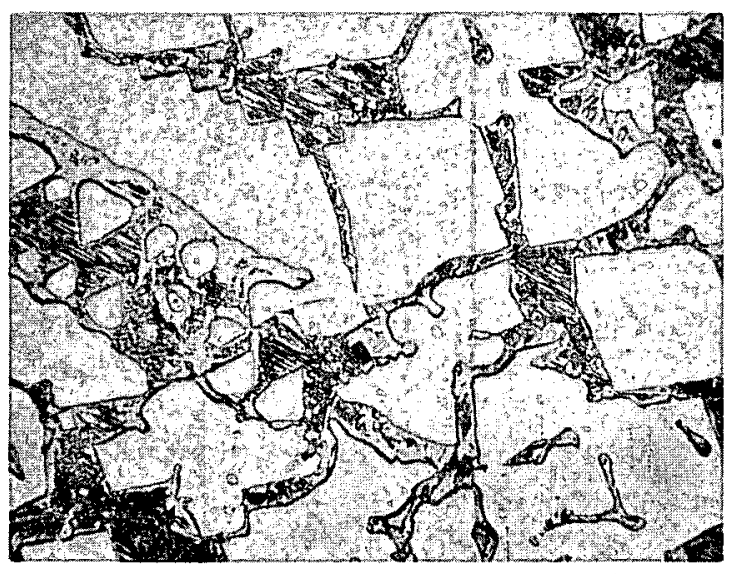

(c) $100 \mathrm{x}$

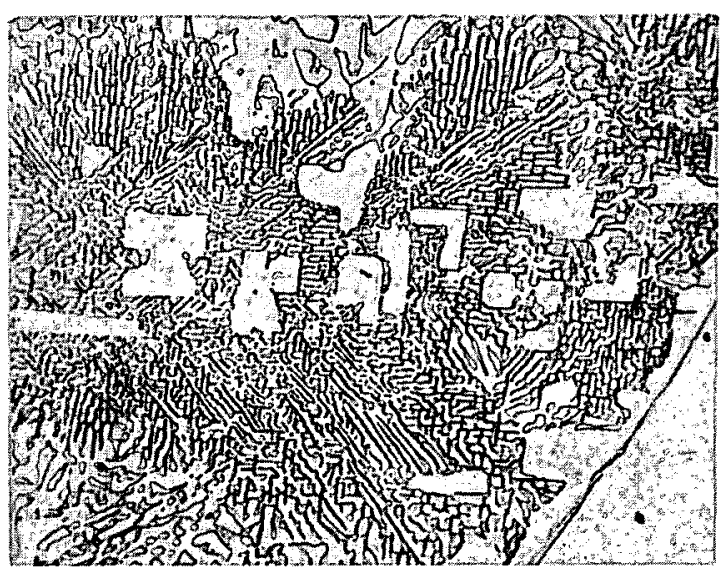

(d) $500 \mathrm{x}$

Fig. 12-Microstructures of uranium-iron alloys in the as-cast condition (electrolytic etch). (c), (d) 54.7 atomic per cent iron; massive $\mathrm{UFe}_{2}$ plus eutectic $\mathrm{UFe}_{2}$ in $\mathrm{U}_{6} \mathrm{Fe}$. 


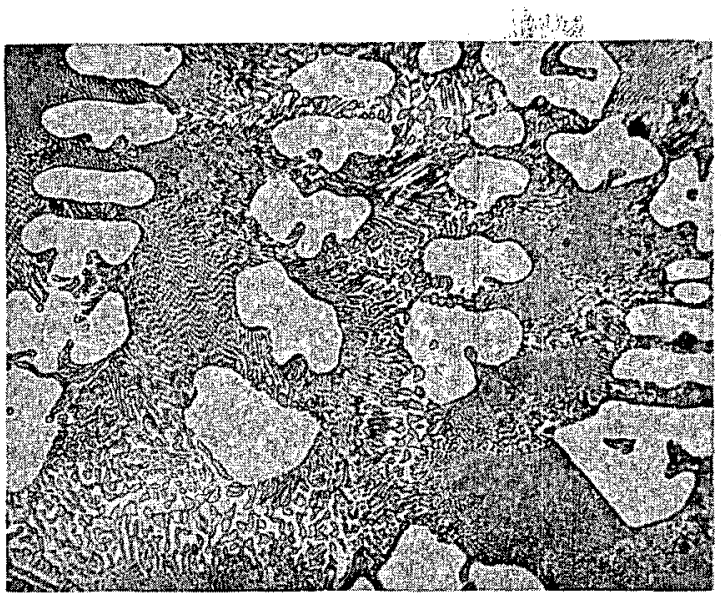

(a) $100 \mathrm{x}$

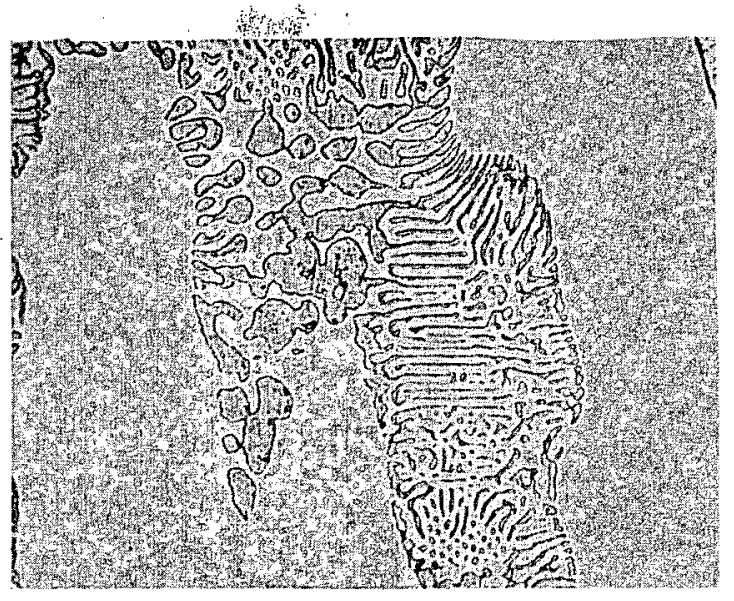

(b) $500 \mathrm{X}$

Fig. 14-Microstructures of uranium-iron alloys in the as-cast condition (nital etch). (a), (b) 80.5 atomic per cent iron; massive $\mathrm{UFe}_{2}$ plus eutectic of $\mathrm{Fe}$ in $\mathrm{UFe}_{2}$.

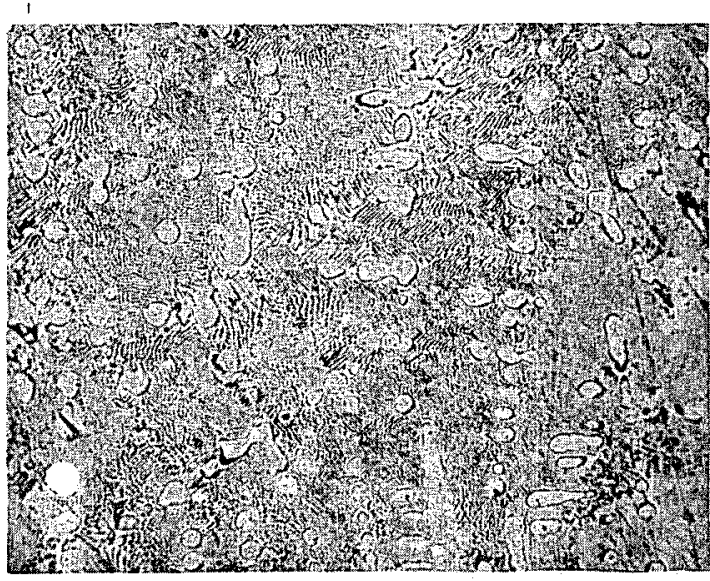

(c) $100 \mathrm{x}$

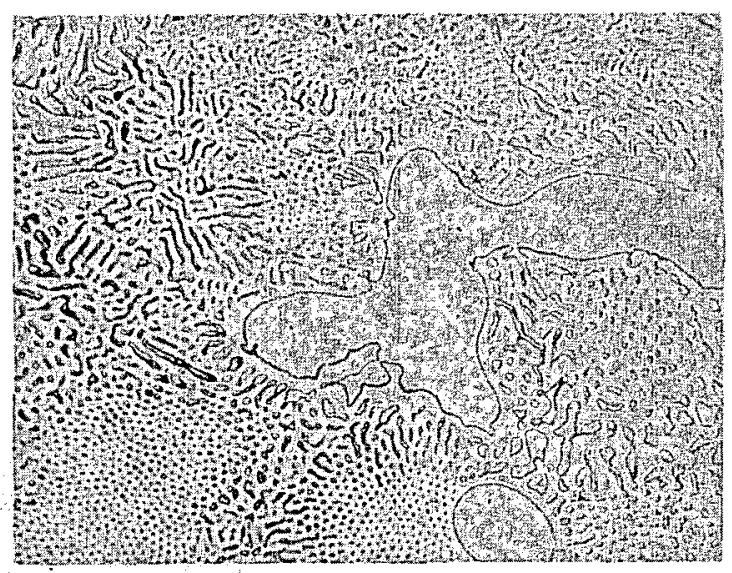

(d) $500 \mathrm{x}$

Fig. 14-Microstructures of uranium-iron alloys in the as-cast condition (nital etch). (c), (d) 85.7 atomic per cent iron; massive Fe plus eutectic of $\mathrm{Fe}$ in $\mathrm{UFe}_{2}$. 


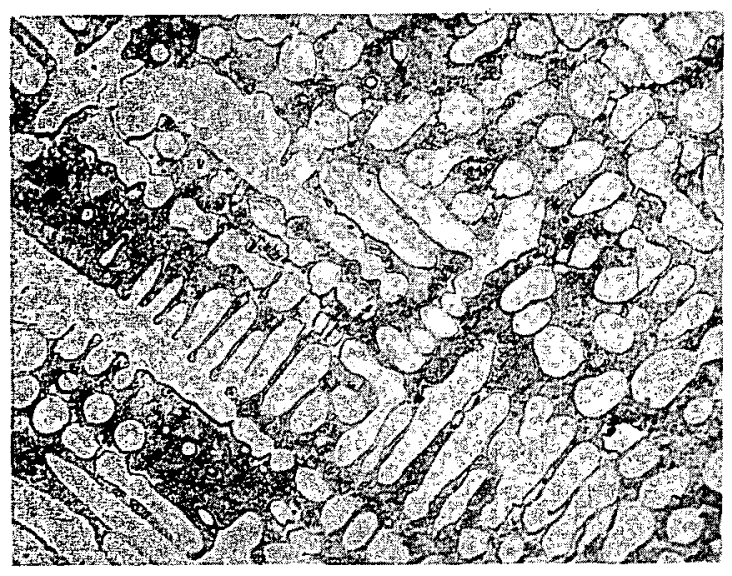

(a) $100 \mathrm{x}$

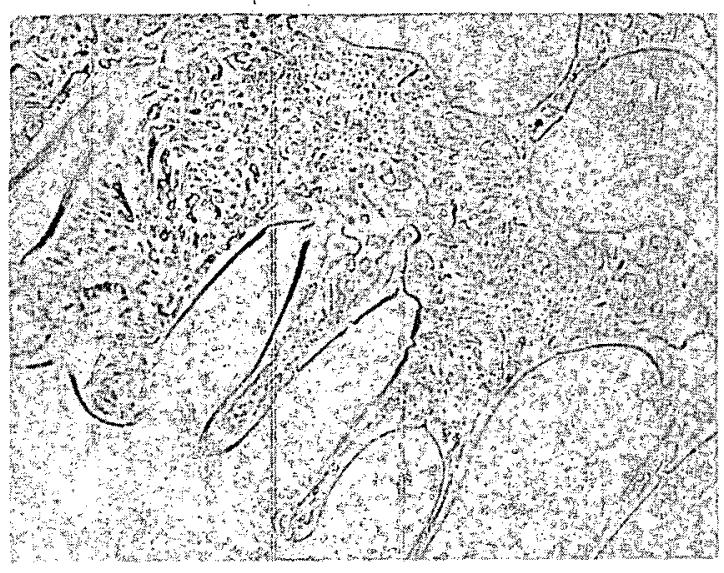

(b) $500 \mathrm{X}$

Fig. 16- Microstructures of uranium-iron alloy containing 91.8 atomic per cent iron-after quenching from just below and just above the transformation temperature $\left(910^{\circ} \mathrm{C}\right)$ for alpha to gamma iron (nital etch). (a), (b) Alloy quenched from $904^{\circ} \mathrm{C}$.

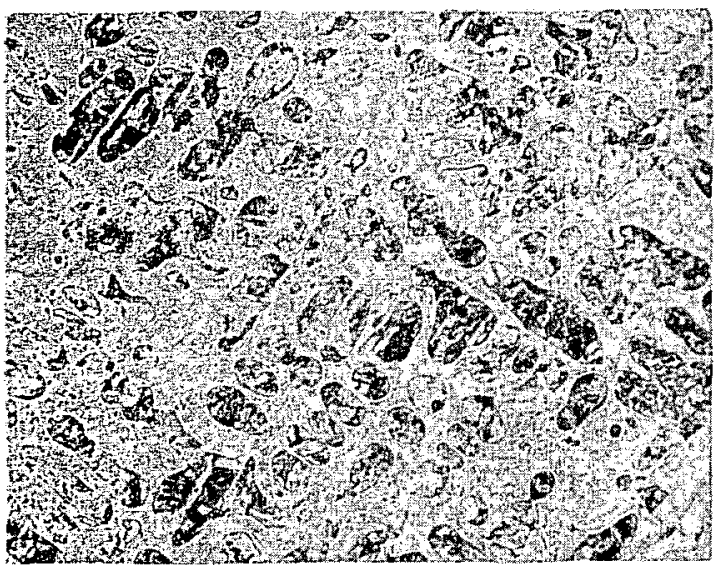

(c) $100 \mathrm{x}$

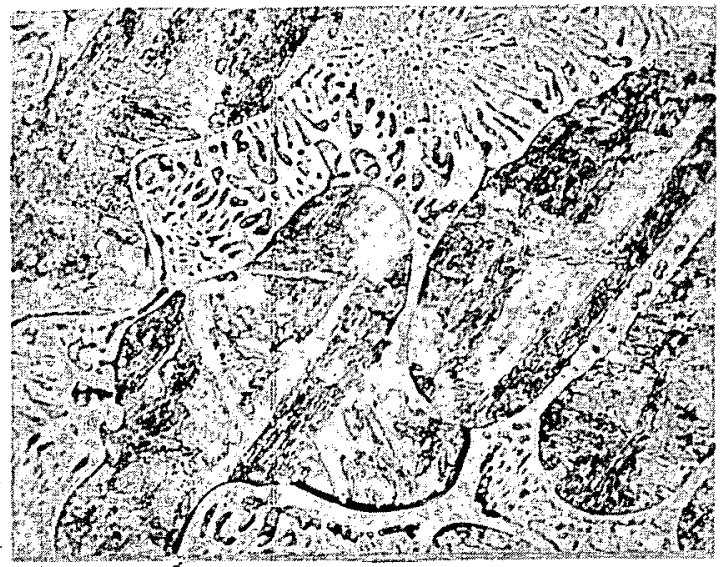

(d) $500 \mathrm{X}$

Fig. 16-Microstructures of uranium-iron alloy containing 91.8 atomic per cent iron - after quenching from just below and just above the transformation temperature $\left(910^{\circ} \mathrm{C}\right)$ for alpha to gamma iron (nital etch). (c), (d) Alloy quenched from $917^{\circ} \mathrm{C}$. Widmanstätten structures in iron phase indicate steel has passed through the alpha to gamma transformation. 